\title{
Subjectivity in journalistic discourse: the case study of issue 810 in the Moroccan weekly TEL QUEL
}

\author{
Ismail Zahidi ${ }^{1 *}$, and Zouhir Zighighi ${ }^{2}$ \\ ${ }^{1}$ IbnTofail University, FLLA, Laboratory of Language and society, Kenitra, Morocco \\ ${ }^{2}$ IbnTofail University, FLLA, Laboratory of Language and society, Kenitra, Morocco
}

\begin{abstract}
This research is part of the theoretical framework of discourse analysis and was designed within an enunciative approach. It represents a cross-domain of linguistics and information science. It focuses on media communication, particularly the question of enunciative positioning within the journalistic discourse. Indeed, this work proposes to study the subjectivity in the issue entitled: «Boycott, les raisons d'un ras-le-bol », published on May $4^{\text {th }}, 2018$, by the Moroccan weekly TEL QUEL.
\end{abstract}

\section{Introduction}

This paper aims to study subjectivity in a journalistic dossier published in a French-speaking Moroccan newsmagazine. Thus, it is part of the analysis of discourse based on the enunciative process. This approach is to identify and describe the relationships that develop between the speaker's speech (the journalist in our case) and the elements that constitute the framework enunciation and the linguistic units, often called the marks of enunciation. Our approach follows the work of Alain Rabatel on the enunciative positioning.

We start from a corpus extracted from the Moroccan French-speaking weekly TEL QUEL, which deals with the boycott campaign that took place in Morocco in April 2018 and that notably, affected CENTRAL DANONE, AFRIQUIA SERVICE STATIONS, and SIDI ALI (a mineral water brand). The treatment of this subject by the written press should be neutral and free from any bias. According to journalism experts, the dossier is part of the so-called objective types of information. This means that the enunciating journalist should, normally, adopt discursive strategies that allow him to detach himself and create a distance from what he presents. However, the norm of objectivity is today contested by journalists themselves. Our aim is, therefore, to draw attention to the issue of objectivity and subjectivity in the media field. The following questions can guide our work: How does the journalist fit into his speech? In other words, what enunciative position does he take in his speech? What are the indicators that fall within its commitment? What are the forms of subjectivity that can appear in a journalistic dossier?

To answer these questions, we will first highlight two theoretical concepts, namely enunciation and subjectivity. In a second step, we will present the specificity of the journalistic file, and we will finish our article by analyzing the corpus subject of our study.

\section{Enunciation and subjectivity}

\subsection{Enunciation}

We cannot talk about the enunciation without mentioning Emile BENVENISTE. BENVENISTE defines enunciation as: « la mise en fonctionnement de la langue par un acte individuel d'utilisation [1] ». It is, therefore, a mental and physical act by which the speaker appropriates the language. Dominique MAINGUENEAU says: "on définit l'énonciation comme l'acte individuel d'utilisation de la langue pour l'opposer à l'énoncé, objet linguistique résultant de cette utilisation [2] ». So, enunciation is the centre of the relationship between the language and its context of production. On the one hand, it makes it possible to represent facts in the statement. On the other hand, it is itself a unique fact defined in time and space.

\footnotetext{
*Corresponding author: ismail.zahidi@uit.ac.ma
} 


\subsection{Subjectivity and enunciation}

The notion of subjectivity has an essential place within the theory of enunciation. Indeed, subjectivity means that which relates to the personality, impressions and state of consciousness of the speaking subject. According to BENVENISTE, subjectivity is: "la capacité du locuteur à se poser comme sujet [3] ». The speaker achieves this using any element referring to the communication situation, namely the time of the enunciation (tense and aspects of the verbs); and the deictics (I-you, here, now). This means that any speaker who says "I " explicitly marks his subjectivity. The enunciator, therefore, leaves explicit or implicit enunciative traces in his speech, and it is possible to identify them.

Talking (or writing) subject occupies an important place in discourse analysis. He is distinguished by his status (social, professional), his ideology, his credibility, his ethos (the discursive image he gives himself), etc.

\section{Dossier: a hybrid genre}

\subsection{Presentation of the corpus}

Our corpus is a dossier published on May $4^{\text {th }}, 2018$, on the issue 810 in TEL QUEL. It is written by journalist Ghita ISMAILI. This dossier, which deals with the boycott campaign under the following title: «Boycott, les raisons d'un ras-le-bol », seeks to explain the reasons for this unprecedented protest movement in Morocco.

This dossier includes nine pages, with more than 4400 words. To get an overview of the issue, this dossier covers several genres at once. We then find elements of analysis, interviews and reports. Each article addresses the problem from a given angle. Indeed, this dossier contains six texts. The first (the dominant article) seeks to find answers and explain the causes of this boycott campaign, reporting the views of several specialists and politicians. The second text is a report entitled: «L'Essence du Boycott ». This report highlights the scale of the boycott within Moroccan society by presenting testimonies of citizens. The dossier also contains an interview with Abderrahmane RACHIK, a sociologist and specialist in social movements. He answers his interviewer's questions by explaining the reasons for this protest movement. There are also three other articles shorter than the previous ones. One of them, entitled «Effets du boycott: l'omerta des entreprises », deals with boycott's effect on the companies targeted by this campaign. The other article takes stock of the support of some artists for this protest movement, and the last article, which takes the following title: "ler mai, l'eau honnie », reports the reaction of the participants of Labor Day parade, who refuse to buy SIDI ALI. To analyze such a subject in-depth, the dossier is, therefore, the appropriate genre.

\subsection{Journalistic dossier:}

The dossier is a set of journalistic texts. It is not a journalistic genre per se, but rather a complex structure that spans several pages. Through various angles, the dossier aims at complete knowledge of a subject. Among the few theorists who have worked on journalistic hyperstructures are Jean-Michel ADAM and Gilles LUGRIN. For them, hyperstructure is : "une structure co-textuelle regroupant, au sein d'une aire scripturale n'excédant pas la double page, un ensemble de textes-articles accompagnés la plupart du temps par des iconotextes photographiques et/ou infographiques [4] ». ADAM and LUGRIN show that these co-texts, which deal with the same media event, are generally gathered under a general title, and unified by a dominant article or hyper-article and by a framework delimiting the perimeter of the hyperstructure. Beyond the double page, we can talk about the dossier. This one is more fragmented and potentially much more complex. We can therefore say that dossier is a journalistic hyperstructure that goes beyond the double page.

Indeed, dossier seeks to examine an event, situation or problem and to the related elements with each other. The chosen treatment can be done according to several modalities in parallel: it can contain portraits, interviews, analyses, and sometimes even journalistic investigations.

\section{Analysis of subjectivity in the dossier section of issue 810 of TEL QUEL}

Journalistic discourse is mainly based on respect for professional ethics, the main pillars of which are objectivity, neutrality and impartiality. However, like any speech, it is subject to two main constraints: a strong enunciative inking on the one hand and an enunciative erasure on the other hand. Indeed, the enunciating journalist, according to Catrine KERBRAT-ORECCHIONI, has the choice between two types of formulations: "le discours objectif, qui s'efforce de gommer toute trace de l'existence d'un énonciateur individuel [et] le discours subjectif, dans lequel l'énonciateur s'avoue explicitement ou se pose implicitement comme la source évaluative de l'assertion [5] ».

Our objective is to identify the signs of subjectivity and commitment present in this dossier. 


\subsection{Deictics}

Deictics are words of a speech that find their place in the enunciation. In other words, they are words whose interpretation or understanding necessarily requires a return to the situation of enunciation. MAINGUENEAU says : «Ces morphèmes ne peuvent être interprétés que si on les rapporte à l'acte d'énonciation unique qui a produit l'énoncé à l'intérieur duquel ils se trouvent [6] ». Indeed, we can only define the referent of a deictic in relation to the interlocutors involved in the situation of enunciation.

We distinguish the person deictic, space deictic and temporal deictic.

\subsubsection{Person deictics}

Person deictics are units that refer to the enunciation and participate in the actualization of a statement, such as the pronouns «I » and «You », or «We » and «You », which designate the transmitter and receiver of the speech. MAINGUENEAU says : "on ne peut interpréter un énoncé contenant Je et/ou Tu qu'en prenant en compte l'acte individuel d'énonciation qui les supporte [...] c'est l'acte de dire Je qui donne le référent de Je, de la même manière c'est l'acte de dire Tu à quelqu'un qui fait de lui l'interlocuteur [7] ».

In the dossier that is the subject of our study, we note the total absence of the couple "Je/Tu », which refers respectively to the speaker (the journalist) and his interlocutor (the reader). This suggests that the enunciating journalist is trying to detach himself. However, it is not only « Je » that allows posing as an enunciator and « $T u$ » to constitute others as an allocator, this role can be held by «Nous » and «Vous ». We have identified 16 occurrences of «Nous ", which refers to the enunciating journalist. This reveals the presence and involvement of the journalist in his speech, as shown in the examples below. "Nous » can refer to a single person or several people when it refers to the enunciator and his interlocutor («Nous » inclusive).

(1) Message reçu 5 sur 5, nous confirme Abderrahmane Rachik, qui a une connaissance pointue des mouvements sociaux plus traditionnels.

(2) Son débit de mitraillette ne nous a pas laissé le temps de lui signaler que Ä̈n Atlas appartient aussi au groupe de MiriemBensalah.

(3) "Nous sommes avec le peuple", scandent tel un mantra des boycotteurs que nous avons sondés.

(4) C'est avec cette formule, devenue presque un mantra, que l'un des serveurs entame son argumentaire pour nous expliquer les raisons de substitution de la petite bouteille de Sidi Ali.

(5) "Adressez-vous plutôt au département de la communication et du marketing", nous lance notre interlocuteur avant de nous demander de quitter les lieux.

The enunciating journalist is, therefore, takes the form of "Nous », which includes "Je », which presents the information and reports the words of others.

Regarding the deictic «Vous », we have identified four occurrences, three of which refer to the people interviewed by the journalist during the interview (examples $6,7,8$ ); only one occurrence refers to reader (9).

(6) Certains commentateurs ont déjà baptisé ce boycott de "20-février économique". Comment voyez-vous l'évolution de ce mouvement?

(7) Quelle est selon vous la typologie des boycotteurs?

(8) Comment jugez-vous le discours tenu par certains politiques comme Mohamed Boussaïd ou Moncef Belkhayat à l'encontre des boycotteurs?

(9) On en appelle à la nation comme à l'époque où on vous expliquait qu'il fallait voter Istiqlal ou ne pas consommer les produits français pour ne pas être un traître.

Deictics related to the category of the person are not limited to the two couples "Je/Tu », and "Nous/Vous », but there are also possessive determinants. There are three occurrences in the corpus that refer to the speaker, as shown in the examples below $(5,10$, and 11$)$ :

(10) $[\ldots]$ analyse notre spécialiste en communication de crise.

(11) $[\ldots]$ conclut notre expert.

We have also noticed in the corpus the use of the «On». From a syntactic point of view, «On» behaves like «Je», « $T u$ », or « $I l »$ with which it switches. " $O n »$ can be given a generic or non-generic interpretation. In this latter case, it can take all values (I, you, we, you, the public rumour, someone, etc.), except for well-identified individuals. We have identified in our corpus three occurrences of « $O n$ » that refer to the enunciator:

(12) Sans former la masse du mouvement, on retrouve d'ailleurs parmi les relayeurs d'anciens activistes du 20février et des soutiens du Hirak.

(13) Au milieu des gens en colère contre la Société des eaux d'Oulmès, on trouve aussi ce vendeur d'eau mélangée à du jus de citron.

(14) Au centre-ville cette fois, le kiosquier en face du Royal Mansour, sur l'avenue des FAR, fait la moue quand on l'interroge sur les packs de Sidi Ali entassés devant les journaux. 
The morpheme «On» have the syntactic properties of «Je », «Tu», «Il», and « Nous ». This explains its importance in the French-language personal system. From the examples $(12,13,14)$, we can deduce that the deictic «On» refer to the enunciator, or the enunciator and his team (the instance of production).

\subsubsection{Spatial and temporal deictics:}

There are other deictics whose function is to inscribe speech in space and time with the point of reference that constitutes the enunciator. These are spatial deictics and temporal deictics. MAINGUENEAU says : "le point de repère des déictiques spatiaux c'est la position qu'occupe le corps de l'énonciateur lors de son acte d'énonciation [8] ». MAINGUENEAU distinguishes three types of spatial deictics: demonstratives, presentatives and adverbials. He also distinguishes between anaphoric deictics and situational deictics. These are often accompanied by a gesture indicating to the allocutaire a perceptible object in the communication situation. In our corpus, all demonstratives are anaphoric, as shown by the following examples:

(15) En moins d'une semaine, le mouvement a pris de l'ampleur auprès des Marocains qui ont fait leur cette nouvelle arme de protestation.

(16) Il est au contraire partisan du boycott par solidarité mais aussi car cela ne nuit pas à son chiffred'affaires.

(17) Aziz Akhannouch s'est retrouvé à cristalliser la colère sur les inégalités sociales, incarnant ce sentiment de hogra vécu par beaucoup de Marocains vis-à-vis des hommes d'affaires, accusés de leur proximité avec le pouvoir.

(18) Ceci sur la base de données recueillies auprès de 38 stations-services.

For adverbial spatial deictics, we have identified the following occurrences:

(19) Non loin de là, sur le boulevard Zerktouni, le café Amistad, appartenant à l'ex-international marocain Salaheddine Bassir, a aussi changé de fournisseur d'eau minérale.

(20) Mais là, elle a particulièrement choqué car elle réduisait les "Marocains, et notamment les classes les plus défavorisées, à de vulgaires consommateurs qui devraient acheter et se taire”.

(21) Nous explique le serveur d'un café situé non loin des Twin.

These adverbial elements $(19,21)$ refer to the situation of enunciation and bear traces of the location of the enunciator. As for temporal deictics, we could identify them to the moment of enunciation, which is the moment when the enunciator speaks or writes. Here are the examples that we found from the corpus:

(22) Aujourd'hui, il écoule péniblement deux ou trois bouteilles par jour à des touristes logeant dans les hôtels alentours.

(23) Aujourd'hui, il veut se venger et participe activement au boycott, après avoir dans un premier temps juste arrêté de passer commande de Sidi Ali car ses clients ne l'achetaient plus.

(24) Tout a commencé le 20 avril dernier avec un appel sur Facebook.

These elements $(22,23$, and 24) will not be understood, if we do not know when this statement was completed.

Through the deictics (of person, space and time) that we have released from the corpus, we can touch the presence and involvement of the journalist in his speech.

\subsection{Summary}

From this analysis, we note that the journalist seeks to give the illusion of objectivity. The strategies of enunciative erasure are the most dominant. We noticed a total absence of «Je » that refers to the enunciating journalist, the omnipresence of the reported speech and the presence of non-embraced statements. The journalist's voice is hidden behind other voices. Therefore, to search for the reasons for the boycott campaign, the author of our corpus gives voice to a specialists (Bouazza KHERRATI, president of the FNDC; Abdelali BENAMOUR, President of the Competition Council; Abderrahmane RACHIK, sociologist; Hamid FARIDI, communication specialist, etc.), artists (Don BIGG, Issam KAMAL, Latifa RAAFAT), grocers, café waiters, consumers, etc. The author of the dossier overlooks all the positions and interventions of the actors on the reasons for this boycott campaign. The journalist plays the role of a distributor of words.

In addition, our analysis shows the presence of several indications of the enunciative commitment of the author of the dossier. Despite the absence of the deictic «Je», which refers to the enunciator journalist, we have spotted a strong presence of the deictic «Nous» (16 occurrences) and «On». Spatial and temporal deictics are also present. We have also identified modalization signs that show the involvement and commitment of the enunciator. It is, therefore, in the way of presenting, naming and illuminating the facts that the enunciating journalist slips through appreciative modalities, often considered as prototypical traces of subjectivity.

Indeed, the journalist's commitment is not limited to the mere presence of the signs of the enunciation. The journalist is, however, responsible for the selection of information, the staging of the event, the selection of quotations and the specialists interviewed, etc. Thus, Alain RABATEL says: "Les journalistes sont responsables, non seulement du choix des mots, de la sélection et de la combinaison des informations, de la gestion de la polyphonie, mais encore des grilles à partir desquelles la réalité est appréhendée [9]». 


\section{Conclusion}

To sum up, this paper focuses mainly on the enunciative positioning in the dossier published on May $4^{\text {th }}, 2018$, in issue 810 of TEL QUEL. It is the subjectivity of the enunciating journalist that we have dealt with in this work. Therefore, we can say that the enunciative positioning in the journalistic discourse oscillates between a commitment and an enunciative erasure. Indeed, the enunciating journalist consciously chooses his positioning according to the genre, the theme and the context of the writing. The quest for objectivity is constantly confronted with the subjectivity of the enunciator or even with the subjectivity of language. Subjectivity is an intrinsic characteristic of language marked in various forms in all languages. It is, therefore, difficult to speak of a completely objective discourse.

\section{References}

[1] E. Benveniste, Problèmes de Linguistique Générale 2, Édition Gallimard, Paris. P 80. (1974)

[2] D. Maingueneau, L'énonciation en Linguistique Française, Paris, Hachette Supérieur. P. 7 (1991).

[3] E. Benveniste, Problèmes de Linguistique Générale 1, Gallimard edition, Paris. P. 269. (1966)

[4] J-M. Adam, G. Lugrin, Effacement énonciatif et diffraction co-textuelle de la prise en charge des énoncés dans les hyperstructures journalistiques, Semen [En ligne], $22 \mid 2006$, mis en ligne le 21 août 2007, consulté le 28 mars 2021. URL : http://journals.openedition.org/semen/4381; DOI : https://doi.org/10.4000/semen.4381

[5] C. Kerbrat-Orecchioni, L'énonciation: De la subjectivité dans le langage, Fourth edition, Paris: Armand Colin, COLLECTION U • LINGUISTICS. (2009)

[6] D. Maingueneau, L'Enonciation en Linguistique Française, ed 1, Paris: Hachette Supérieur. P. 9. (1991).

[7] D. Maingueneau, L'Enonciation en Linguistique Française, ed 1, Paris: Hachette Supérieur. P. 17. (1991).

[8] D. Maingueneau, L'Enonciation en Linguistique Française, ed 1, Paris: Hachette Supérieur. P. 27. (1991).

[9] A. RABATEL, L'effacement de la figure de l'auteur dans la construction événementielle d'un "journal" de campagne électorale et la question de la responsabilité, en l'absence de récit primaire, Semen - Revue de sémio-linguistique des textes et discours, Presses Universitaires de l'Université de Franche. County (Pufc), pp.71-85. <halshs$00367531>* \$,(2006)$. 